\title{
Actinomycetes from the Coffee Plantation Soils of Western Ghats: Diversity and Enzymatic Potentials
}

\author{
Banu Sameera ${ }^{1}$, Harishchandra Sripathy Prakash ${ }^{2}$ and Monnanda Somaiah Nalini ${ }^{1}$ * \\ ${ }^{1}$ Department of Studies in Botany, ${ }^{2}$ Department of Studies in Biotechnology, University of \\ Mysore, Manasagangotri, Mysore-570 006, Karnataka, India \\ *Corresponding author
}

\section{A B S T R A C T}

230 soil actinomycetes were isolated from the coffee plantation of Western Ghats, Karnataka, India along the altitudinal gradients and depths. 24 morphologically distinct species were obtained based on the aerial spore chains and by the sequencing of the $16 \mathrm{~S}$ rRNA gene. The strains were assigned to the order Micrococcales, and novel orders Pseudonocardiales ord. nov., Streptomycetales ord. nov., and Streptosporangiales ord. nov. The frequently isolated genus was Streptomyces, along with rare actinomycetes Actinomadura, Spirillospora, Actinocorallia, Arthrobacter, Saccharopolyspora and Nonomuraea. This study is the first report on Nonomuraea antimicrobica as a soil actinomycete. Diversity studies on the distribution of soil actinomycetes indicated significant differences $(\mathrm{P}<0.05)$ among Shannon diversity indices of sample group depths along the slope. An attempt was made to correlate the total actinomycete count with soil parameters, by PCA based multiple linear regression (MLR) which significantly correlated $(\mathrm{P} \leq 0.0001)$ with $\mathrm{pH}$, moisture, available nitrogen and phosphorous. About $91.6 \%$ of the isolates screened were found to be potentials for enzymatic activity. The most active enzyme producer Streptomyces sp. MH470335 produced 18.51, 1.53, 6.92, 5.62 and 5.15 $\mathrm{U} / \mathrm{ml}$ for cellulase, pectinase, xylanase, amylase and protease respectively. Plantation soil actinomycetes showing enzymatic activities in vitro may indicate the potential for their use as stabilized biocatalysts.

\section{Introduction}

Plantation ecosystems are a potential niche for microorganisms. They play a significant role in decomposing and transforming wide variety of complex organic residues in the plantation soils derived from the fallen crop residues and from shade trees. Plantation soil supports actinomycete populations (George et al., 2012) that help to decompose various biomolecules by producing extracellular enzymes. The actinomycetes are aerobic, filamentous Gram-positive bacteria with high $\mathrm{G}+\mathrm{C}$ content in their DNA.

Bioprospection of underexplored ecosystems have been proven as useful habitats for exploiting numerous bioactive metabolites from novel actinomycetes (Shah et al., 2017). Actinomycetes are known for the production of extracellular enzymes with applications in agriculture and industries (Mukhtar et al., 
2017). Though, soil actinomycetes are preferred for their novel bioactive potentials, these organisms have not been explored at greater depths from plantation areas.

Few actinomycetes from plantation regions are potentially rich sources of antimicrobial compounds (Manikkam et al. 2014). There are a few reports on the actinomycete diversity from plantation areas, especially from the coffee plantation areas of the southern Western Ghats. Nevertheless, studies are focused to improve the soil quality parameters for coffee productions and estimating the microbial diversity based on shade and open tree canopy types (Velmourougane, 2017). There is no proper documentation on the systematic identification of actinomycetes based on the colony, sporangial characters and $16 \mathrm{~S}$ rRNA sequences.

Therefore, the study area was selected in the coffee plantation area of Chikmagalur, southern India which is so far unexplored for the actinomycete isolations and diversity studies. Coffee (Coffea arabica L.) is an important plantation crop, cultivated commercially in high altitude regions of southern India.

The heterogeneous tree populations here not only provides a regulated shade system to the coffee canopy, but the characteristic leaf and fruit shedding along with the crop residues favor the buildup of diverse microorganisms (Bagyaraj et al., 2015).

The objectives of this study were focused on the isolation and characterization of soil actinomycetes and studying their interaction with physicochemical properties of soil along the elevation and soil depth gradients in the coffee plantation area and as well to determine their enzymatic potentials.

\section{Materials and Methods}

\section{Study site description and sampling}

The study was conducted in the coffee plantation area of the Chikmagalur region $\left(13.4333^{0} \mathrm{~N}\right.$ to $\left.75.7500^{\circ} \mathrm{E}\right)$ of Western Ghats, southern India (Fig. 1a) situated at an elevation of $1000 \mathrm{~m}$ above mean sea level. The mean temperature and rainfall documented in the study site ranges from $13^{\circ} \mathrm{C}$ to $35^{\circ} \mathrm{C}$ and 15000 to $20000 \mathrm{~mm}$ respectively. To accomplish the aim of the present study, an altitudinal transect with same environmental conditions, except slope positions were determined with an approximate area of five hectares, under cultivation. The area under study was divided into three parts: toe slope (base), back slope (mid) and the summit (top) (Fig. 1b). In each part, two soil profiles viz. surface soil (5-15 $\mathrm{cm})$ and sub-surface soil $(15-30 \mathrm{~cm})$ was sampled. Five typical major plots (10 m x 10 m) were selected at $0.5 \mathrm{~km}$ intervals within the study area. Each major plot was divided into five minor plots of $1 \mathrm{~m} \times 1 \mathrm{~m}$ dimension selected through the five point method (Zhang et al., 2014). Five soil samples were randomly collected from these plots, pooled as composite sample and were air dried at room temperature $\left(25{ }^{\circ} \mathrm{C} \pm 2\right)$ and preserved in zip locked polyethylene bags. All the soil samples were collected in triplicates.

Isolation and molecular characterization of actinomycetes from coffee plantation soils

\section{Isolation of actinomycetes from soil samples}

The isolation of soil actinomycetes was carried out by suspending one gram of dry soil in $100 \mathrm{ml}$ of distilled water. Serial dilutions of soil samples (up to $10^{-5}$ ) were done aseptically and $100 \mu \mathrm{l}$ suspensions of each dilution were spread evenly over the surface of starch casein agar (SCA) medium 
in triplicates supplemented with cycloheximide $(100 \mu \mathrm{g} / \mathrm{ml})$, nystatin $(100$ $\mu \mathrm{g} / \mathrm{ml})$ and nalidixic acid $(50 \mu \mathrm{g} / \mathrm{ml})$ (Himedia ${ }^{\circledR}$, Mumbai, India) by the spread plate technique (Kumar et al., 2014). The plates were incubated at $28{ }^{\circ} \mathrm{C} \pm 2$ for two to four weeks. The actinomycete colonies on the plates were counted for each dilution and colony forming units per gram of soil was calculated. The colonies were individually isolated by streak plate technique for purification on ISP2 (International Streptomyces Project type-2, Himedia ${ }^{\circledR}$, India, $41 \mathrm{~g} / \mathrm{l})$ media. The pure cultures were transferred to ISP2 agar slants and maintained at $4{ }^{\circ} \mathrm{C}$ for further studies and glycerol $(20 \%$ v/v) stocks at $-20^{\circ} \mathrm{C}$.

\section{Identification of soil actinomycetes}

The purified isolates were identified by morphological characteristics such as the colony morphology and growth pattern under stereo zoom microscope (Lawrence \& Mayo $^{\circledR}$, India). The isolates were observed for the substrate / aerial mycelium and spore chains in methylene blue stain and observed under bright field microscopy (Quasmo ${ }^{\mathrm{TM}}$, India) using 100x oil immersion objective. The representative isolates were identified based on Bergey's Manual of Systematic Bacteriology (Goodfellow et al. 2012).

Molecular characterization of the isolates involved the extraction of genomic DNA and amplification of 16S rRNA gene by the universal primers $27 \mathrm{~F}$ and $1492 \mathrm{R}$ according to the procedure of Akshatha et al. (2014) using Genomic bacterial DNA isolation kit and PCR kit respectively (Chromous Biotech ${ }^{\circledR}$ Pvt. Ltd., Bangalore, India). The sequences of isolates were aligned for the similarity and homology against the reference sequences using the $\mathrm{BLAST}^{\circledR}>>$ blasting site provided by NCBI and submitted to the NCBI GenBank submission portal to obtain the accession numbers.

\section{Physico-chemical characteristics of soil}

Soil color was determined by Munsell ${ }^{\circledR}$ soil color charts. Soil moisture content and $\mathrm{pH}$ were measured gravimetrically and potentiometrically respectively. The soil organic carbon and available nitrogen (Microkjeldahl method), phosphorus (Bray and Kurtz method) and potassium (neutral normal ammonium acetate extraction method) in the samples were analyzed by standard methods (Jones, 2001).

\section{Screening of actinomycete isolates for enzymatic potentials}

The actinomycete isolates were screened for their ability to produce extracellular enzymes such as cellulase, xylanase, pectinase amylase and proteases. All the isolates were subjected to the primary screening method. The isolates were inoculated on a suitable medium containing specific substrate (cellulose, pectin, xylan, starch and skimmed milk) by the spot inoculation method followed by incubation for five days. The plates were observed for clear zones surrounding the colonies on agar plates and were measured (Lekshmi et al., 2014). The strains exhibiting positive enzyme activity were selected for secondary screening by shake flask fermentation method (Lekshmi et al., 2014).

Cellulase, pectinase, xylanase and amylase enzyme activities were determined by 3,5dinitrosalicylic acid (DNS) assay (Miller, 1959). The universal protease activity assay was used to measure the proteolytic activity, using casein as the substrate (Suthindhiran et al., 2013). The amount of glucose, xylose, polygalacturonic acid, maltose and tyrosine released into the filtrates were measured from the respective standard curves and the enzyme activities were calculated and represented. The specific activity was expressed as enzyme units $\mathrm{mg}$ protein $^{-1}$. The protein content was estimated by Lowry's method 
(Lowry et al., 1951) with the protein standard, bovine serum albumin (1 $\mathrm{mg} / \mathrm{ml})$. The enzyme activities were expressed in terms of international units (IU). One IU was the amount of enzyme required to release one micromole of substrate (reducing sugar/tyrosine) equivalents in one milliliter of enzyme solution in one minute.

\section{Statistical analysis}

The statistical significance of mean differences was determined by the one-way variance of analysis (ANOVA) using SPSS statistical software (version 20.0 for Windows, SPSS, Chicago, IL, USA).

The correlation co-efficient analysis between physico-chemical parameters of soil samples and actinomycetes population relating to two soil profiles along the slope were performed using with principal component analysis (PCA) using PAST (PAleontological STatistics) statistical software version 3.20. The suitability of dataset for PCA was assessed by calculating the correlation coefficients between variables, the determinant of the correlation matrix, KMO measure of sampling adequacy and Bartlett's test of sphericity. The diversity indices measured by Shannon index, Shannon evenness and species richness were performed by PAST. Statistical analysis for enzymatic potentials were studied using analysis of variance (ANOVA) and means were compared for significance using Duncan's multiple Range Test $(\mathrm{P}<0.05)$.

\section{Results and Discussion}

\section{Isolation and molecular characterization of actinomycetes from coffee plantation soils}

A total of 230 actinomycetes (consisting of 24 isolates) were isolated from the plantation study site. The total actinomycete counts in each soils sampled from the toe slope to the summit ranged from $8.30 \times 10^{3}$ to $1.36 \times 10^{6}$ cfu/gof dry soil, depth-wise along the slope (Fig. 2a). Maximum isolates were obtained in the back-slope region followed by, toe slope and summit at the surface soil layer. At the sub-surface soil layer, highest count was in the back-slope followed by summit and toe slope (Fig. 2b). These investigations are in compliance with the findings of Velmourougane et al. (2017) who documented a similar trend in the distribution of actinobacteria in coffee agroforestry systems and reported that high elevation favored more number of microorganisms than lower elevations. On contrary, Krishna et al. (2012) observed that actinomycete populations showed a decreasing trend with increasing depth of soil.

Coffee plantation thrives in well-drained soils rich in humus. It flourishes under a mixed shade canopy of evergreen trees comprising of Erythrina, Ficus, Artocarpus, Grevillea etc. The litter composed of dry leaves of coffee and shade trees which forms primary sources of soil organic matter. The litter deposited favors rich soil organic matter and microbial populations (Martins et al., 2018). Therefore, in this study, sampling of such nutrient rich soils would have favored the isolation of soil actinomycetes.

Based on molecular characterization, of 24 actinomycete isolates, $54.2 \%$ were identified as Streptomyces sp. and $45.8 \%$ as nonstreptomycetes or rare actinomycetes (Fig. 3). The colony characteristics on ISP2 media, spore morphology and GenBank accession numbers with percent similarity are depicted in Table 1. The isolates comprised of seven genera representing four orders (Micrococcales, Pseudonocardiales ord. nov., Streptomycetales ord. nov., Streptosporangiales ord. nov.). Actinomycetes Nocardia, Micromonospora, Streptomyces, Rhodococcus and Streptosporangium are reported from rubber and teak plantation soils 
based on physiological characterization (George et al., 2012).

Actinomycetes were identified as Streptomycetes and non-streptomycetes from the rubber and coffee plantation soils of Kerala, India based on the phenotypic characteristics (Manikkam et al., 2014). Similar studies were reported from oil palm plantation, Malaysia (Zain et al., 2014; Shariffa-Muzaimah et al., 2015), mulberry and banana plantations (Kawuri, 2016).

Diversity studies on the distribution of soil actinomycetes along the altitudinal gradient

The species diversity values determined using the Shannon index was compared with the Wilcoxon signed-rank test. There was a significant difference $(\mathrm{P}<0.05)$ among the Shannon diversity indices of sample group depths along the slope. The range of biodiversity indices of all sampling points is depicted in Table 2. The frequently isolated genus was Streptomyces, followed by rare actinomycetes Actinomadura, Spirillospora, Actinocorallia, Arthrobacter, Saccharopolyspora and Nonomuraea.

The frequency of the genera Streptomyces and Actinomadura was $50 \%$ and $32.2 \%$, respectively, whereas, the other genera such as Spirillospora (6.32\%), Actinocorallia (5.08\%), Arthrobacter (3.3\%) and Nonomuraea $(2.1 \%)$ recorded low frequency and Sachharopolyspora $(0.8 \%)$ showed very low frequency. Two genera viz., Saccharopolyspora and Nonomuraea were found exclusively on summit of both soil profiles. Conversely, Arthrobacter on toe slope of both the soil profiles.

The genera, Spirillospora and Actinocorallia were found in the back slope and summit of both the soil profiles. The species diversities of Streptomyces among the back slope isolate were significantly higher $(\mathrm{P}<0.05)$ than those of the toe slope isolates and summit isolates. On the contrary, diversity of Actinomadura species among back slope isolates was significantly higher $(\mathrm{P}<0.05)$ than that of the summit and toe slopes.

So far, no attempt has been made to identify and assign the actinomycetes isolated from the plantation soils to particular order/family/taxa through a systematic approach. Identifications were based on the morphological and sporangial characteristics. This is the first comprehensive report on the identification of plantation soil actinomycetes by 16s rRNA approach. This study is important in reporting Nonmuraea antimicrobica as a soil actinomycete, which is otherwise reported as an endophyte from a Chinese medicinal plant (Qin et al., 2009).

\section{Correlation of physico-chemical soil characteristics and total actinomycete count by principal component analysis (PCA)}

In this analysis, six sample groups were assessed along eight variables viz. $\mathrm{pH}$, soil moisture content (SMC), electrical conductivity (EC), organic carbon (OC), available nitrogen (AN), available phosphorous (AP), available potassium (AK) and total actinomycete count (TAC) for generating PCA biplot. The PCA was used to deduce the correlation between physicochemical parameters of the soil and total actinomycete counts relating to two soil profiles.

The Kaiser-Meyer-Olkin (KMO) measure of sampling efficacy (0.608) and Bartlett's test of sphericity $\left(\mathrm{X}^{2}=88.460\right.$, df $\left.=21, \mathrm{P}<0.0001\right)$ showed the suitability of dataset for PCA application. Figure 4 represents the PCA biplot with two principal components PC1 and PC2 with $44.571 \%$ and $21.093 \%$ of variance respectively. 
Table.1 Colony characteristics and GenBank accession numbers of actinomycete strains from the coffee plantation soils

\begin{tabular}{|c|c|c|c|c|c|c|}
\hline \multirow{2}{*}{$\begin{array}{l}\text { Isolate } \\
\text { Code }\end{array}$} & \multirow[t]{2}{*}{ Actinomycete Strain } & \multirow{2}{*}{$\begin{array}{l}\text { Accession } \\
\text { no. }\end{array}$} & \multirow[t]{2}{*}{ Similarity \% } & \multicolumn{3}{|c|}{ Colony Characteristics } \\
\hline & & & & Color & Pigments & Spore characteristics ${ }^{*}$ \\
\hline CMCS 01 & Streptomyces coelicolor & KY492192 & 95 & Yellow & Brown & Rectiflexibiles (smooth) \\
\hline CMCS 02 & Streptomyces hebeiensis & KY498018 & 95 & $\begin{array}{l}\text { Deep grey-yellow- } \\
\text { brown }\end{array}$ & $\begin{array}{l}\text { Deep yellow } \\
\text { brown }\end{array}$ & Rectiflexibiles (warty) \\
\hline CMCS 03 & Streptomyces atrovirens & KY498019 & 98 & Grey & Greyish green & Spirales (hairy) \\
\hline CMCS 04 & Streptomyces olivaceous & KY511125 & 100 & Greyish yellow & Olive colored & Spirales (smooth) \\
\hline CMCS 05 & Streptomyces spectabilis & KY555725 & 100 & light reddish brown & Reddish orange & Rectiflexibiles (smooth) \\
\hline CMCS 06 & Streptomyces clavuligerus & KY555726 & 100 & Light greyish white & - & Rectuiflexibiles (smooth) \\
\hline CMCS 07 & Streptomyces griseoplanus & KY563319 & 100 & Greyed yellow & - & Spirales (Warty) \\
\hline CMCS 08 & Arthrobacter viscosus & KY563320 & 99 & Light pink & - & Spherical \\
\hline CMCS 09 & Streptomyces longisporoflavus & KY563321 & 100 & Colorless & - & Spirales/retinaculi aperti(smooth) \\
\hline CMCS 10 & Nonomuraea antimicrobica & MH392729 & 100 & Brown & - & Spiral spore chains \\
\hline CMCS 11 & Streptomyces violaceolatus & MH393284 & 99 & Grey & Blue/violet & Spirales (smooth) \\
\hline CMCS 12 & Streptomyces rubrogriseus & MH393288 & 100 & Raspberry red & - & Spirales (smooth) \\
\hline CMCS 13 & Streptomyces chattanoogensis & MH393287 & 100 & Pale white & - & Spirales/retinaculiaperti (spiny) \\
\hline CMCS 14 & Streptomyces mutabilis & MH393285 & 100 & White & - & $\begin{array}{l}\text { Aberrant Spirales/retinaculi aperti } \\
\text { (smooth) }\end{array}$ \\
\hline CMCS 15 & Actinomadura nitritigenes & MH470330 & 99 & Brown Mahagony & - & Chain of spore (smooth) \\
\hline CMCS 16 & A. montaniterrae & MH470332 & 99 & Dark greyish yellow & $\begin{array}{l}\text { Greyish greenish } \\
\text { yellow }\end{array}$ & A chain of four spores (rough) \\
\hline CMCS 17 & Actinomadura sp. & MH470334 & 100 & Leathery white & - & Spore chains hooked (smooth) \\
\hline CMCS 18 & Streptomyces sp. & MH470335 & 100 & Grey & greyish & Spirales \\
\hline CMCS 19 & Actinomadura apis & MH470336 & 100 & Colorless & - & Chain of 3-5 spores (warty) \\
\hline CMCS 20 & Spirillospora albida & MH470337 & 99 & Buffy pink & Pale yellow & Spherical spore vesicles \\
\hline CMCS 21 & Actinomadura rifamycini & MH472581 & 100 & Brown & Brown pigment- & Chain of 3-8 spores (warty) \\
\hline CMCS 22 & Saccharopolyspora hattusasensis & MH472618 & 100 & Pale white & - & $\begin{array}{l}\text { Long chain of spores arranged in } \\
\text { open loops }\end{array}$ \\
\hline CMCS 23 & Actinomadura namibiensis & MH478193 & 99 & Salmon pink & - & Spiral spore chains (smooth) \\
\hline CMCS 24 & Actinocorallia libanotica & MH489087 & 100 & Greyish & - & Spore chains in hooks (warty) \\
\hline
\end{tabular}

* Based on the Bergey's manual of systematic bacteriology (Goodfellow et al. 2012) 
Table.2 Species diversity of soil actinomycetes depth wise along the altitudinal gradient

\begin{tabular}{|l|c|c|c|c|c|c|}
\hline Diversity Indices & TS_S & Su_s & BS_s & TS_ss & Su_ss & BS_ss \\
\hline Taxa_S & 3 & 6 & 4 & 2 & 6 & 4 \\
\hline Individuals & 35 & 35 & 37 & 17 & 54 & 58 \\
\hline Dominance_D & 0.7453 & 0.2718 & 0.4215 & 0.5848 & 0.3951 & 0.4762 \\
\hline Simpson_1-D & 0.2547 & 0.7282 & 0.5785 & 0.4152 & 0.6049 & 0.5238 \\
\hline Shannon_H & $\mathbf{0 . 5 0 6 3 ^ { a }}$ & $\mathbf{1 . 5 0 1}$ & $\mathbf{1 . 0 1 5}^{\mathbf{c}}$ & $\mathbf{0 . 6 0 5 8}$ & $\mathbf{1 . 2 5 6}$ & $\mathbf{0 . 8 6 7}^{\mathbf{f}}$ \\
\hline Evenness_e^H/S & 0.553 & 0.7478 & 0.6902 & 0.9164 & 0.5852 & 0.595 \\
\hline Brillouin & 0.4284 & 1.293 & 0.8934 & 0.5136 & 1.115 & 0.7897 \\
\hline Fisher_alpha & 0.7855 & 2.084 & 1.139 & 0.5887 & 1.727 & 0.975 \\
\hline Berger-Parker & 0.8571 & 0.4286 & 0.5405 & 0.7059 & 0.5926 & 0.5862 \\
\hline
\end{tabular}

$\mathrm{P}<0.05$ different letter indicates the significant difference by Wilcoxon signed rank test, TS-toeslope, Su-summit, BS-backslope,_s- Surface soil, _ss- subsurface soil

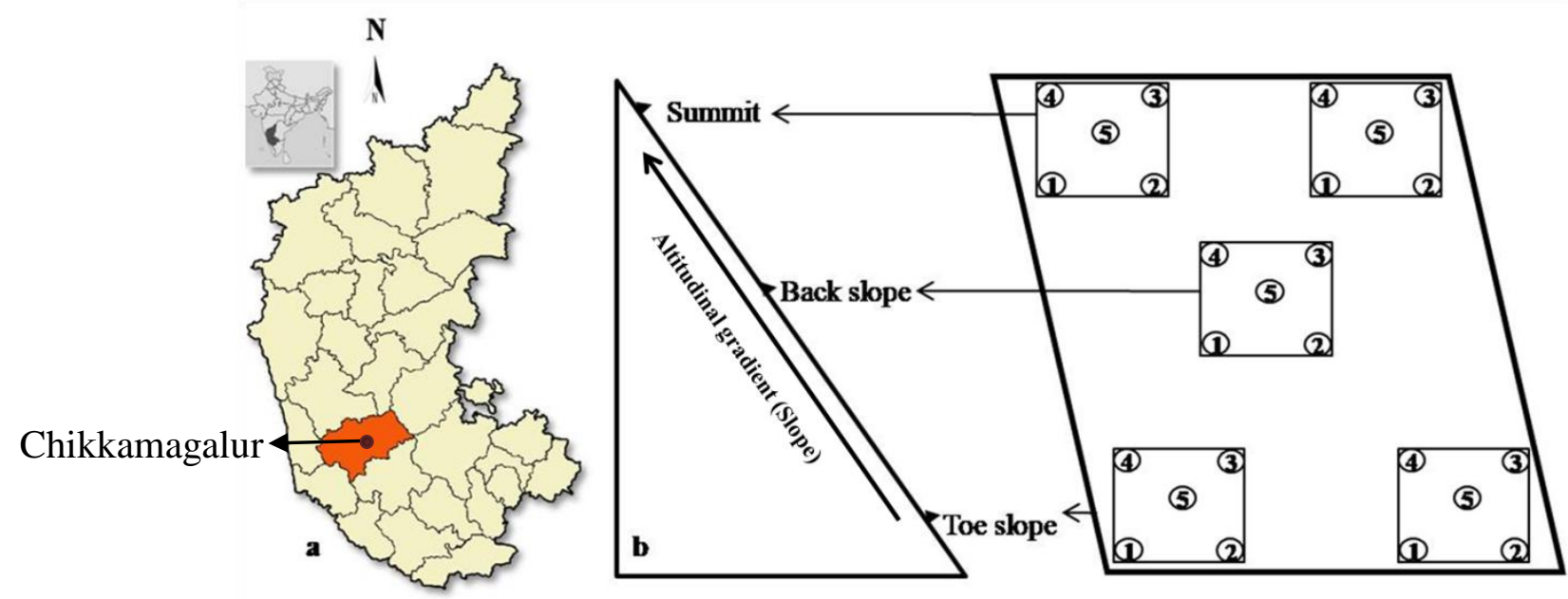

Figure 1 Study Area of coffee plantation soil sampling site in Chikmagalur, Karnataka, India
a. Map of Karnataka with Chikkamagalur, the plantation sampling site
b. Five point

sampling method with altitudinal gradient 
A

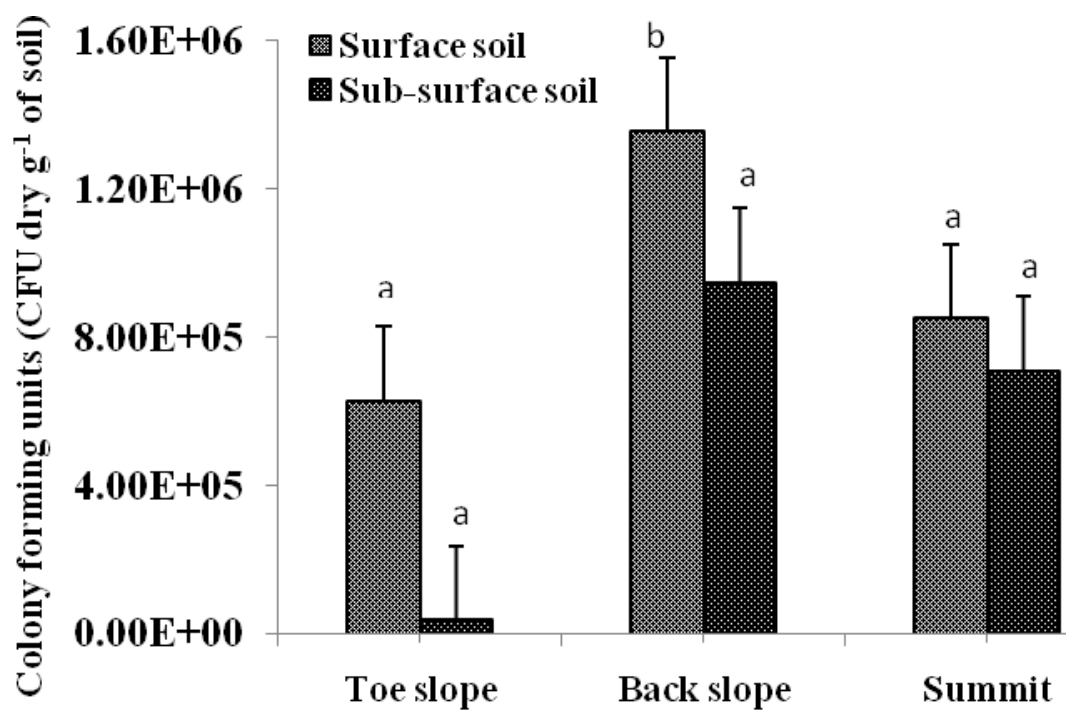

Soil profile along the slope

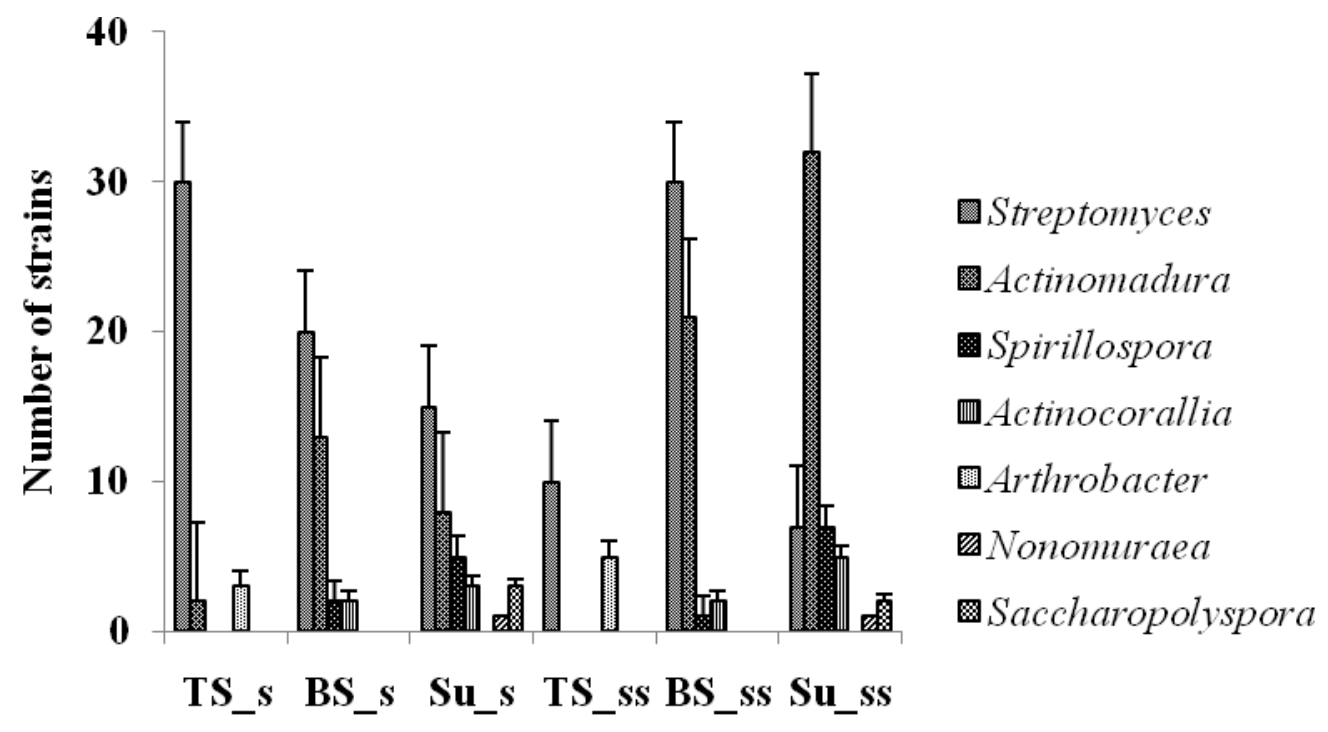

B

Soil profile along slope

Figure 2 Actinomycetes recovered from the plantation sampling site along the altitudinal gradient and soil depth

A. Population (mean \pm SD) of actinomycetes at two soil profiles along the altitudinal gradient. Different letters differ significantly $(\mathrm{P}<0.05)$ based on Duncan's Multiple range test

B. Number of actinomycete strains in the soil profiles along an altitudinal gradient TS- Toe slope, BS - Back slope, Su- Summit, s-surface, ss-sub surface 


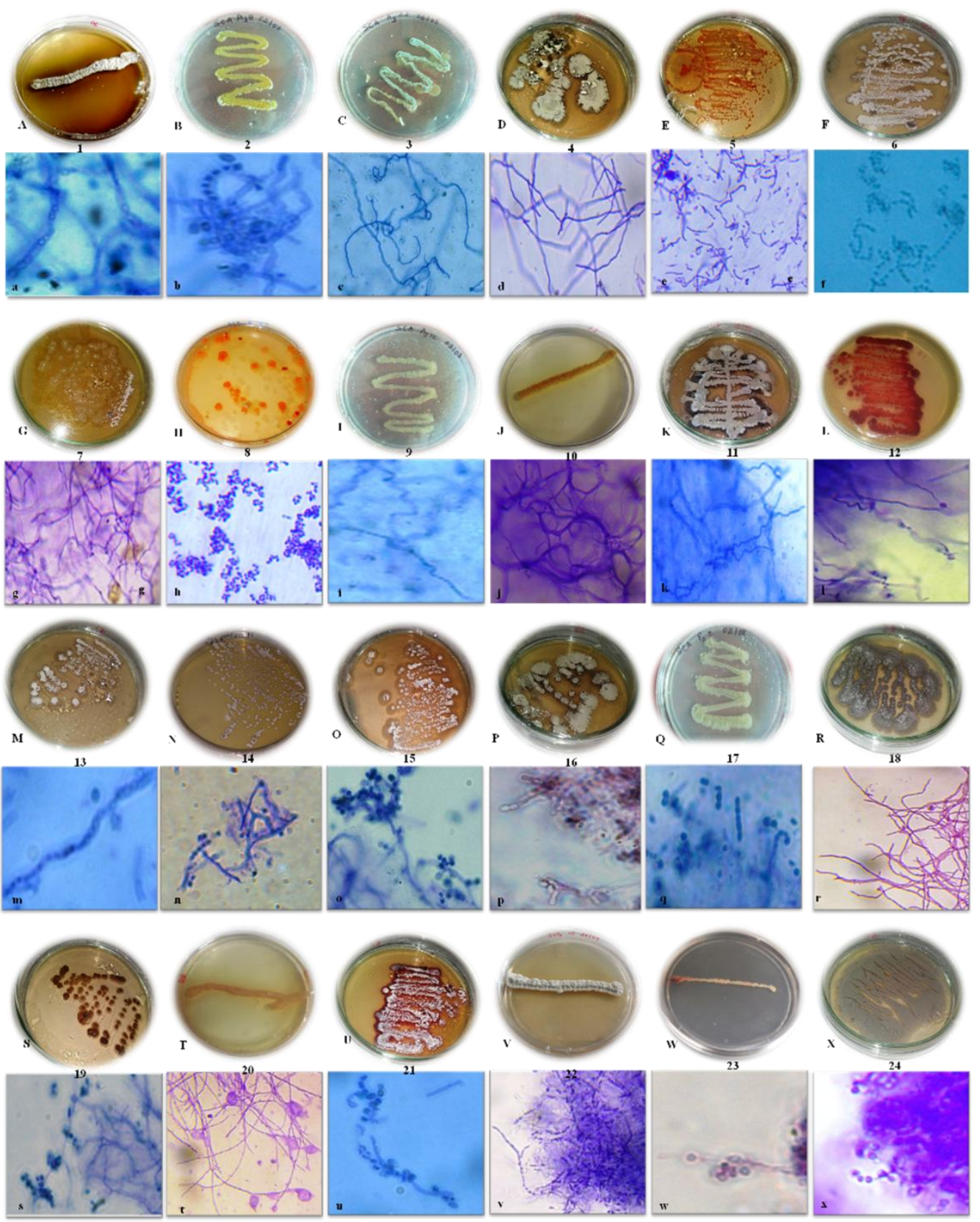

Figure 3 Plantation soil actinomycete strains on ISP-2 medium and their aerial spores

1. S. coelicolor 2. S. hebeiensis 3. S. atrovirens 4. S. olivaceous 5. S. spectabilis 6. S. clavuligerus 7. S. griseoplanus 8. A. viscosus 9. S. longisporoflavus 10. N. antimicrobica 11. S. violaceolatus 12. S. rubrogriseus 13. S. chattanoogensis 14. S. mutabilis 15. A. nitritigenes 16. A. montaniterrae 17. Actinomadura sp. 18. Streptomyces sp. 19. A. apis 20. S. albida 21. A. rifamycini 22. S. hattusasensis 23. A. namibiensis 24. A. libanotica; Letters in upper case represents on plate colony; Letters in lower case represents light microscopy photographs at 100X magnification. 


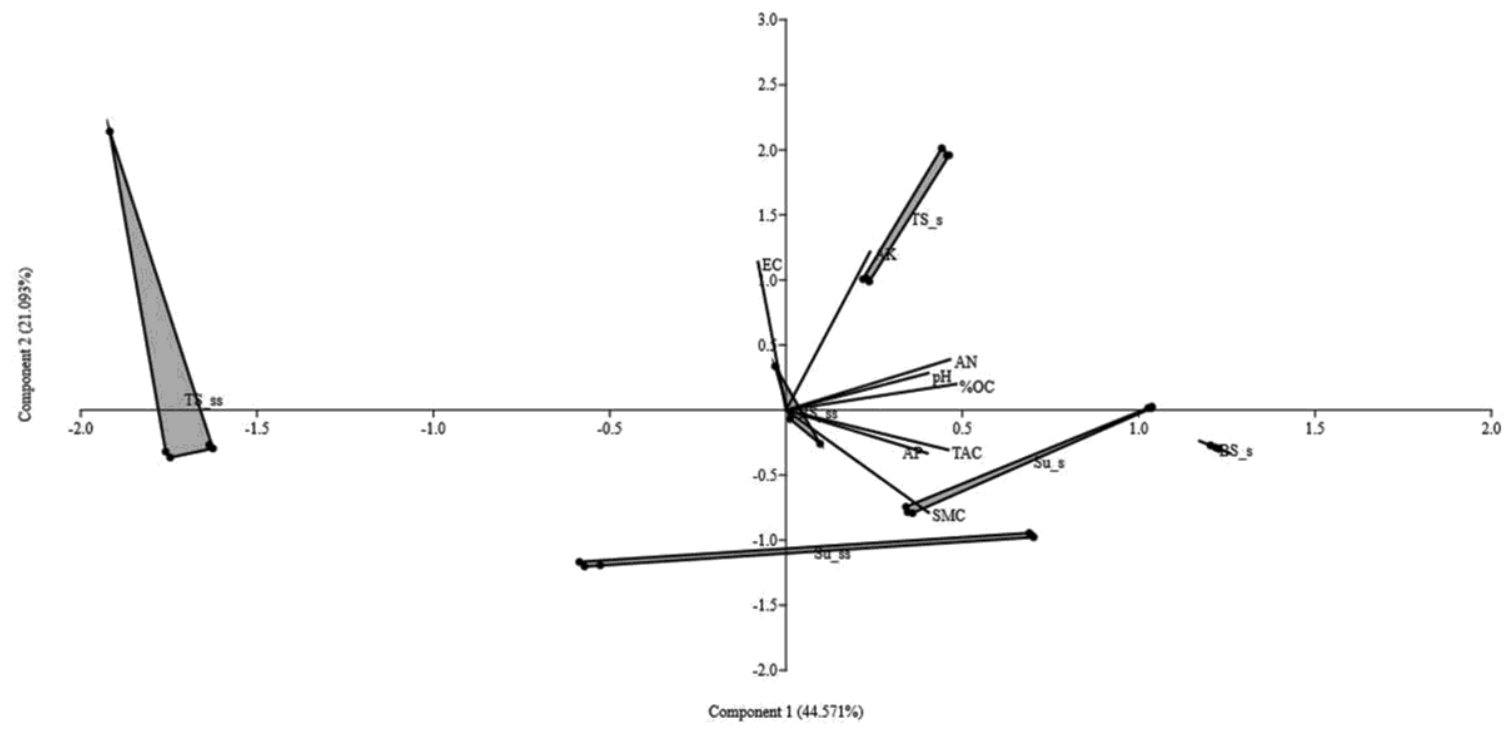

Figure 4 Biplot of principal component analysis (PCA)

TAC-total actinomycetes count, SMC- soil moisture content, EC- Electrical conductivity, OCOrganic carbon, AN- Available nitrogen, AP- Available phosphorus, AK- Available potassium, TS-toe slope, Su-summit, BS-back slope,_s- Surface soil, _ss- subsurface soil

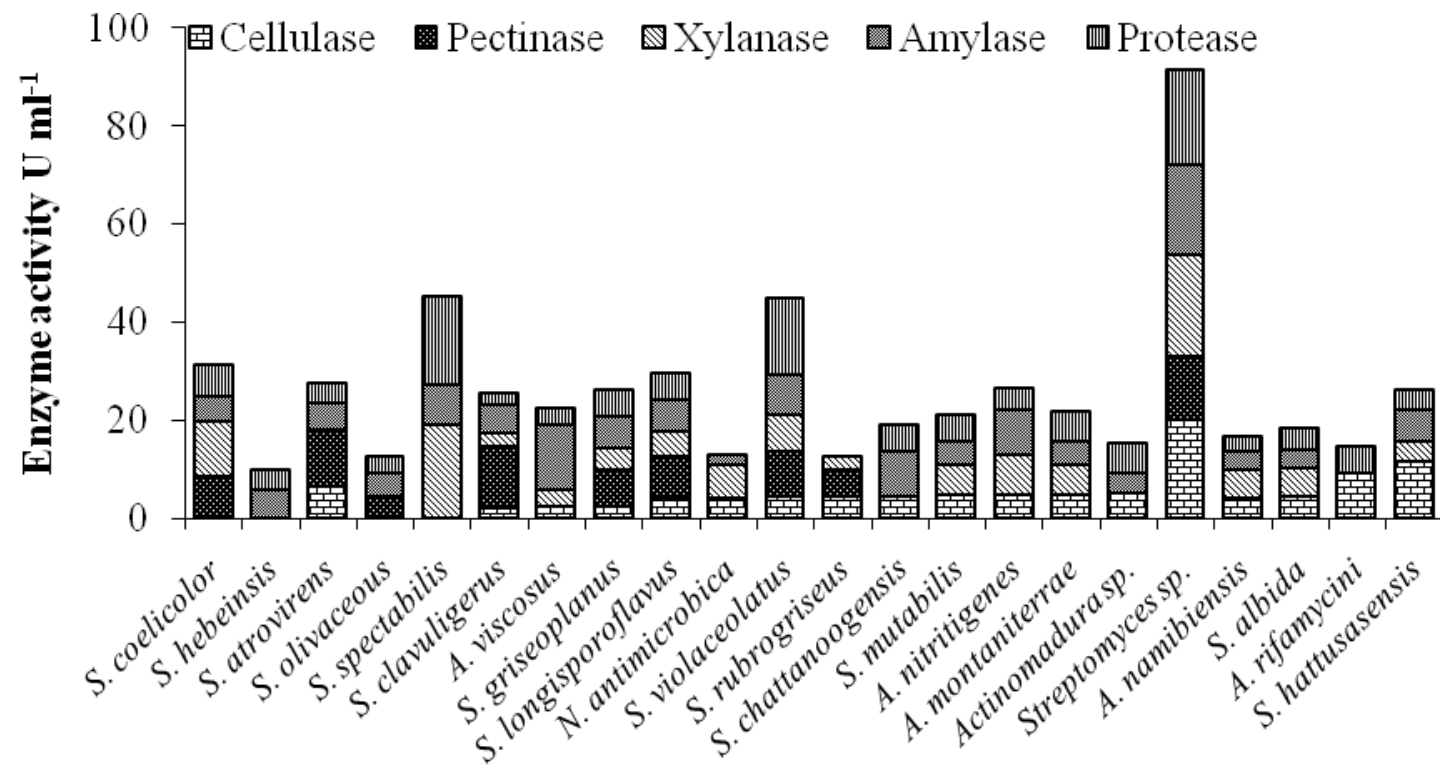

Soil actinomycete strains

Figure 5 Enzyme activity $(\mathrm{U} / \mathrm{ml})$ of actinomycete isolates Each value represents the mean \pm SEM of triplicate experiments 
The TAC variable correlated with variables AN, AP and SMC through positive loadings for PC1. The correlated variable $\mathrm{AK}$ and $\mathrm{EC}$ with positive loadings and high contributions for PC2 is associated with a separate variable group. Along with SMC and \%OC with negative PC2 loadings and high contribution to PC2- these variables contrasts the slope position (i.e. Toe slope, summit and back slope). The surface soil groups, i.e. TS_s have positive PC2 scores and a content abundance of EC and AK variables compared with other groups with negative scores and SMC and \%OC content abundance compared with the groups along the slope. Thus, SMC, $\% \mathrm{OC}, \mathrm{EC}$ and $\mathrm{AK}$ are responsible for group distinction along the slope. The outcome of PCA based MLR analysis demonstrated that $\mathrm{PC} 1(\mathrm{P}=<0.0001)$ and $\mathrm{PC} 2(\mathrm{P}=0.014)$ had a significant effect on TAC and considered for $47.4 \%$ and $45.78 \%$ of total variation in the TAC to subsurface soil and surface soils. Previous investigations have shown significant or no correlations between soil properties and actinomycete populations. Jehangir et al. (2012) reported no correlation between the physicochemical parameters of forest soil versus actinomycete populations. But, investigations by Priyadarshini et al. (2013) on the physico-chemical properties viz. $\mathrm{pH}$, moisture, organic matter, nitrogen and phosphorous content in paddy field soils showed significant correlation with actinomycete populations.

Screening of actinomycete strains for enzymatic potentials

The actinomycetes isolated from coffee plantation soil exhibited remarkable enzymatic potentials. The results of the preliminary screening revealed that $62.5 \%$, $33.3 \%, 54.2 \%, 70.8 \%$ and $79.2 \%$ of the strains showed cellulase, pectinase, xylanase, amylase and protease enzymatic potentials respectively, while $20.8 \%$ of the strains were found to produce all the enzymes. During the secondary screening, all tested isolates showed enzyme activities, between 0.360 to $18.51 \mathrm{U} / \mathrm{ml}$ for Cellulase, 0.86 to $1.53 \mathrm{U} / \mathrm{ml}$ for pectinase, $0.65-6.92 \mathrm{U} / \mathrm{ml}$ for xylanase, $0.26-5.62 \mathrm{U} / \mathrm{ml}$ for amylase on day 6 at $50^{\circ} \mathrm{C}$ at $\mathrm{pH} 7.0$ and $2.63-5.15 \mathrm{U} / \mathrm{ml}$ for protease on day 6 at $30^{\circ} \mathrm{C}$ at $\mathrm{pH} 7.0$ and the results are represented in Figure 5. The optimum enzyme activity was exhibited by Streptomyces sp. for all enzyme activities studied. Earlier reports on the enzymatic potentials of actinomycetes indicate that approximately $90 \%$ of the isolates possessed one or more potentials (Lekshmi et al., 2014; Singh and Roymon, 2018). The complexity of plantation habitats comprising a cool temperature and shade with special lighting conditions that in turn contributes to the potential to produce a wide range of enzymes by actinomycetes.

Actinomycetes, especially Streptomyces, are reported from the plantation habitats. From this study, it is clearly indicated that coffee plantation system can be considered as an important resource for screening useful enzyme producing actinomycetes. Further, investigations are required to elucidate the potentials of these organisms for enzyme production by biotechnological approaches. These isolates may be effectively used in large scale production for commercial, industrial and pharmaceutical applications in the coming future.

Currently we are pursuing the antibiotic potential of soil actinomycetes, as they are known to be novel antibiotic sources.

\section{Acknowledgements}

The first author is thankful to the financial assistance provided by Directorate of Minorities fellowship, Govt. of Karnataka and NON-NETFS, University Grants Commission (UGC, Govt. of India) and facilities utilized 
from the Institution of Excellence-University of Mysore,

\section{Conflict of interest}

The authors declare that there is no conflict of interest involved in this study.

\section{References}

Akshatha VJ, Nalin MS, D'Souza C and Prakash HS, Streptomycete endophytes from anti-diabetic medicinal plants of the Western Ghats inhibit alpha-amylase and promote glucose uptake. Letters in Applied Microbiology 2014, 58(), 433439.

Bagyaraj DJ, Thilagar G, Ravisha C, Kushalappa CG, Krishnamurthy KN and Vaast P, Below ground microbial diversity as influenced by coffee agroforestry systems in the Western Ghats, India. Agriculture Ecosystems and Environment 2015, 202(), 198-202.

George M, Anjumol A, George G and Hatha M, Distribution and bioactive potential of soil actinomycetes from different ecological habitats. African Journal of Microbiology Research 2012, 6(), 22652271.

Goodfellow M, Kampfer P, Busse H-J, Trujillo ME, Ludwig W, Suzuki K-i and Whitman WB, 2012. Bergey's manual of systematic bacteriology volume $\mathrm{V}$ The Actinobacteria Part A and B. USA:Springer New York DOI 10.1007/978-0-387-68233-4 pp. 5781966.

Jehangir A, Yousuf AR, Reshi ZA, Tanveer A and Ahmad A, Comparison of physical, chemical and microbial properties of soils in a clear-cut and adjacent intact forest in North Western Himalaya, India. International Journal of Soil Science 2012, 7(), 71-81.

Jones BJ, (2001) Laboratory guide for conducting soil test and plant analysis. USA: CRC press, Taylor and Francis
Group, LLC. pp. 27-178

Kawuri R, Isolation and identification of Streptomyces sp. on rhizosphere plant banana (Musa paradiasica) in Pandem village Jembrana Regency Bali. Journal of Biological Science 2016, 3, 140-148.

Krishna MP, Varghese R and Hatha AAM, Depth wise variation of microbial load in the soils of midland region of Kerala: a function of important soil physicochemical characteristics and nutrients. Indian Journal of Education Information and Management 2012, 1(), 126-129.

Kumar PS, Duraipandiyan V and Ignacimuthu $S$, Isolation, screening and partial purification of antimicrobial antibiotics from soil Streptomyces sp. SCA 7. Kaohsiung Journal of Medical Science 2014, 30, 435-446.

Lekshmi M, Jayadev A and Navami SS, Isolation and screening of actinomycetes from marine samples for enzyme production. International Journal of Science and Engineering Research 2014, 5(), 199-204.

Lowry HO, Rosebrough NJ, Farr AL and Randall RJ, Protein measurement with the Folin phenol reagent. Journal of Biological Chemistry 1951, 193, 265-275.

Manikkam R, Venugopal G, Subramaniam B, Ramasamy B and Kumar V, Bioactive potential of actinomycetes from less explored ecosystems against Mycobacterium tuberculosis and other nonmycobacterial pathogens. International Scholarly Research Notices 2014, 1-9.

Martins JR, Fernandes LA, Oliveira ALG, Sampaio RA, Frazao LA, Soil microbial attributes under agroforestry systems in the Cerrado of Minas Gerais. Floresta $e$ Ambiente 2018 25, 1-9.

Miller GL, Use of Dinitrosalicylic acid reagent for determination of reducing sugar. Analytical Chemistry 1959, 31, 426-428.

Mukhtar S, Zaheer A, Ayesha D, Malik KA and Mehnaz S, Actinomycetes: A source of industrially important enzymes. Journal 
of Proteomics and Bioinformatics 2017, 10, 316-319.

Nasrabadi GR, Greiner R, Alikhani HA and Hamedi J, Distribution of actinomycetes in different soil ecosystems and effect of media composition on extracellular phosphatase activity. Journal of Soil Science and Plant Nutrition 2013, 13, 223-236.

Priyadharsini P, and Dhanasekaran D, Diversity of soil allelopathic actinobacteria in Tiruchirappalli district, Tamilnadu, India. Journal of Saudi Society and Agriculture Science 2013, 14, 54-60.

Qin S, Zhao GZ, Klenk HP, Li J, Xu LH and Li WJ, Nonomuraea antimicrobica sp. nov., an endophytic actinomycete isolated from leaves of Maytenus austroyunnanensis. International Journal of Systematic Evolutionary Microbiology 2009, 59, 2453-2457.

Rezai H, Jafarzadeh AA, Alijanpour, A and Kamran KV, Effect of slope position on soil properties and types along an elevation gradient of Arasbaran forest, Iran. International Journal of Advance Science and Engineering Information Technology 2015, 5, 449-456.

Shah MA, Rasool S, Majeed A, Mushtaq S, Khan HM, Hussain A, Shah A and Hassan PQ, Reappraisal of actinomycetes for novel bioactive metabolites. Annals of Phytomedicine 2017, 6, 13-19.

Shariffa-Muzaimah SA, Idris AS, Dzolkhifhi $\mathrm{O}$, Karamuzzaman $\mathrm{S}$ and Cheong $\mathrm{PCH}$, Isolation of actinomycetes from rhizosphere of oil palm (Elaeis guineesis Jacq.) for antagonism against Ganoderma boninense. Journal of Oil Palm Research 2015, 27, 19-29.

Sharma M, Actinomycetes:Source, identification and their applications. International Journal of Current Microbiology and Applied Sciences 2014, 3, 801-803.

Singh P, and Roymon MG, Enzymatic screening and antibacterial potential of actinomycetes from forest soil of Bastar, India. International Journal of Advance Science Engineering Technology 2018, 6, 21-24.

Suthindharan K, Jayasri MA, Dipali D and Prasar A, Screening and characterization of protease producing actinomycetes from marine saltern. Journal of Basic Microbiology 2014, 54, 1098-1109.

Velmourougane K, Shade trees improve soil biological and microbial diversity in coffee based system in Western Ghats of India. Proc Natl Acad Sci India Sect B Biol Sci 2017, 87, 489-497.

Zain NMM, Mohamad RB, Sijam K and Awang Y, (2014) Isolation and identification of microorganisms from soil in a young oil palm plantation. $J$ Food Agric Environ 12, 443-447.

Zhao Z, Shahrour I, Bai Z, Fan W, Feng L and Li H, (2013) Soils development in opencast coal mine spoils reclaimed for 1-13 years in the West-Northern Loess Plateau of China. European J Soil Biol $55,40-46$.

\section{How to cite this article:}

Banu Sameera, Harishchandra Sripathy Prakash and Monnanda Somaiah Nalini. 2018. Actinomycetes from the Coffee Plantation Soils of Western Ghats: Diversity and Enzymatic Potentials. Int.J.Curr.Microbiol.App.Sci. 7(08): 3599-3611. doi: https://doi.org/10.20546/ijcmas.2018.708.364 